\title{
Optimalisasi Ketersediaan Produk-produk Pertanian Berbasis Organic Farming Menuju Gaya Hidup Sehat melalui Sistem Pertanian Terpadu
}

\section{(Optimizing the Availability of Organic Farming Farm Products Toward a Healthy Lifestyle through Integrated Farming System)}

\author{
Syamsul Hadi ${ }^{*}$, Muhammad Hazmi², Insan Wijaya², Arief Noor Akhmadi ${ }^{3}$, Muhammad Iwan Wahyudi² \\ 1 Program Studi Agribisnis, Fakultas Pertanian Universitas Muhammadiyah Jember, Gumuk Kerang, Karangrejo, \\ Sumbersari, Jember, Jawa Timur 68124. \\ ${ }^{2}$ Jurusan Agroteknologi, Fakultas Pertanian, Universitas Muhammadiyah Jember, Gumuk Kerang, Karangrejo, \\ Sumbersari, Jember, Jawa Timur 68124. \\ ${ }^{3}$ Program Studi Pendidikan Biologi, Fakultas Keguruan dan Ilmu Pendidikan, Universitas Muhammadiyah Jember \\ Gumuk Kerang, Karangrejo, Sumbersari, Jember, Jawa Timur 68124. \\ *Penulis Korespondensi: syamsul.hadi@unmuhjember.ac.id \\ Diterima Juli 2020/Disetujui februari 2021
}

\begin{abstract}
ABSTRAK
Masalah krusial yang dihadapi masyarakat desa sasaran adalah terhambatnya perubahan paradigma masyarakat petani atas proses perubahan pola pikir dan pola tindak dalam sistem budi daya organik dan konvensional. Padahal potensi penerapan pertanian organik di desa tersebut terbuka lebar, karena pasar produk pupuk organik dan pestisida hayati sudah mulai berjalan. Tujuan kegiatan program IbDM ini adalah mengoptimalkan penyediaan produk-produk pertanian yang berbasis organik untuk menuju hidup sehat. Metode pelaksanaan yang digunakan untuk menemukan solusi masalah adalah berupa pendekatan rekayasa sosial dan rekayasa teknologi melalui sosialisasi, desiminasi, dan pelatihan. Pendekatan yang dilakukan terhadap proses rekayasa dimaksud berupa pendekatan partisipatif, pemberdayaan, dan inter entrepreneurial development dalam upaya penguatan kapasitas SDM komunitas dengan melibatkan stakeholders melalui model sistering desa. Hasil pelaksanaan program adalah sebagai berikut: 1) Terlaksananya sosialisasi program IbDM dengan hasil mitra memahami secara tektual tentang konsep dari kegiatan ini dan siap untuk berpartisipasi dalam membangun desa organic; 2) Siklus desa organik sudah dilaksanakan dengan baik dengan terbentuknya kelembagaan Organic Farming Institute (OFI) Al-Istiqomah; 3) Telah dilakukan analisis sampel tanah dengan 10 jenis analisis lengkap dan telah dilakukan pemetaan demplot seluas 3 ha; 4) Telah dilakukan studi banding ke Gapoktan Al-Barokah Bondowoso; 5) Telah dilakukan pelatihan pembuatan bahan-bahan organic; dan 6) Hasil review partisipatif menunjukkan capaian indikator keberhasilan sebesar 65\% dan kinerja OFI sebesar 30,23\% atau semi berdaya dan siap go organic.
\end{abstract}

Kata kunci: desa organik, siklus desa organik, sistering desa

\section{ABSTRACT}

A crucial problem faced by the target village community is the inhibition of changing the paradigm of the farmer community on the process of changing the mindset and action patterns in organic and conventional cultivation systems. In fact, the potential for the application of organic farming in the village is wide open, because the market for organic fertilizers and biological pesticides has started to run. The objective of the IbDM program is to optimize the supply of organic-based agricultural products towards healthy living. The implementation method used to find solutions to problems is in the form of social engineering and technological engineering approaches through socialization and training. The approach taken to the engineering process is in the form of a participatory approach, empowerment, and inter-entrepreneurial development in an effort to strengthen the capacity of community human resources by involving stakeholders through the village system model. The results of program implementation are as follows: 1) Socialization of the IbDM program with the results of partners understanding intellectually about the concept of this activity and are ready to participate in building an organic village; 2) The organic village cycle has been implemented properly with the formation of the Organic Farming Institute (OFI)) Al-Istiqomah; 3) Soil sample analysis has been carried out with 10 types of complete analysis and a 3 hectare demonstration plot mapping has been carried out; 4) A comparative study has been carried out to Gapoktan Al-Barokah Bondowoso; 5) Training has been carried out on the manufacture of organic materials; and 6) The results of the participatory review showed the achievement of success indicators of $65 \%$ and OFI performance of $30.23 \%$ or semi empowered and ready to go organic. 


\section{PENDAHULUAN}

Pemerintah Kabupaten Jember menjadikan Desa Sruni sebagai salah satu desa percontohan bagi penanaman padi melalui sistem pertanian organik. Awalnya hanya seluas 2 ha dan berkembang menjadi 5 ha dengan perolehan produksi sebanyak 7,3 ton/ha. Namun demikian hasil produksi tersebut tidak banyak membuat petani lain ikut untuk mencobanya (Kantor Desa Sruni 2016). Peran Penyuluh Pertanian Lapangan (PPL) sesungguhnya telah tampak dalam upaya mendorong dan merangsang petani untuk ikut andil dalam menerapkan sistem pertanian organik di daerah penelitian. Namun faktanya mereka kurang merespon positif terhadap anjuran PPL yang sudah terbukti dapat meningkatkan produktivitas lahan dengan biaya produksi yang lebih rendah dibandingkan dengan sistem konvensional yang tingkat produksinya rata-rata $<6$ ton/ha. Selain itu, berdasarkan data di Dinas Pertanian Kabupaten Jember (2012) bahwa unsur hara organik yang terkandung dalam tanah sudah berada di bawah $2 \%$.

Masalah krusial yang dihadapi oleh masyarakat desa sasaran khususnya adalah terhambatnya perubahan paradigma masyarakat petani desa sasaran yang coba dibangun oleh sebuah gagasan yang ideal, yaitu pada sudut pandang adanya proses perubahan pola pikir (mindset) dan pola tindak serta lahirnya lembaga petani yang mandiri dan mengakar di masyarakat. Padahal di sisi lain, potensi penerapan pertanian organik di desa tersebut terbuka lebar, karena pasar produk pupuk organik dan pestisida alami/hayati juga tidak kalah besar peluangnya. Sejumlah produk yang dihasilkan secara mandiri akan mampu memenuhi kebutuhan lokal, terlebih masih ada stok pabrikan yang terdistribusi dengan lancar. Namun demikian merubah paradigma masyarakat petani di desa mitra tidaklah mudah, padahal dengan organic farming pendapatan usaha tani akan meningkat.

Sulitnya merubah paradigma masyarakat petani di atas berbeda dengan kasus fenomena yang terjadi di Desa Aan, Kecamatan Banjarangkan, Kabupaten Klungkung, Bali yang merespons positif terhadap sistem pertanian organik. Hal itu ditunjukkan oleh hasil penelitian Widnyana (2011) di desa tersebut yang mengungkapkan bahwa respons petani terhadap kegiatan penanaman padi berbasis organik cukup tinggi. Hasil evaluasinya menyimpulkan bahwa $100 \%$ dari petani SIT mengetahui dan paham tentang budi daya padi sistem organik, dan mereka sepakat mengembangkan sistem budi daya ini di masa mendatang. Sementara hasil penelitian Santoso et al. (2012) di Kecamatan Sambirejo Kabupaten Sragen ditunjukkan bahwa produktivitas padi organik lebih tinggi (7,4 ton/ha) dibandingkan dengan padi anorganik (6,5 ton/ha). Hasil penelitian ini dapat dijadikan salah satu dasar bagi masyarakat petani Desa Sruni selain hasil studi banding ke Botanik Bondowoso untuk segera bergeser dari budi daya padi konvensional menuju budi daya padi organik.

Pertanian organik didasari pada empat prinsip (IFOAM 2009), yaitu prinsip kesehatan, ekologi, keadilan, dan perlindungan. Setiap prinsip dinyatakan melalui suatu pernyataan disertai dengan penjelasannya. Prinsip-prinsip ini harus digunakan secara menyeluruh dan dibuat sebagai prinsip-prinsip etis yang mengilhami tindakan. Prinsip kesehatan adalah bahwa pertanian organik harus melestarikan dan meningkatkan kesehatan tanah, tanaman, hewan, manusia, dan bumi sebagai satu kesatuan dan tak terpisahkan. Sementara itu, prinsip ekologi adalah bahwa pertanian organik harus didasarkan pada sistem dan siklus ekologi kehidupan. Selanjutnya prinsip keadilan dimaksud adalah pertanian organik harus membangun hubungan yang mampu menjamin keadilan terkait dengan lingkungan dan kesempatan hidup bersama. Adapun prinsip perlindungan maksudnya bahwa pertanian organik harus dikelola secara hati-hati dan bertanggung jawab untuk melindungi kesehatan dan kesejahteraan generasi mendatang serta kelestarian lingkungan hidup.

Sejalan dengan fenomena di atas, maka Pasal 4 UU Nomor 06 Tahun 2014 bahwa pengaturan desa sebagaimana pada huruf (d), (h) dan (i) adalah bertujuan mendorong prakarsa, gerakan, dan partisipasi masyarakat desa untuk pengembangan potensi dan asset desa guna kesejahteraan bersama; memajukan perekonomian masyarakat desa serta mengatasi kesenjangan pembangunan nasional; dan memperkuat masyarakat desa sebagai subjek pembangunan. Semangat Pasal 4 ini sejalan dengan RPJM Desa Sruni Tahun 2014-2019 pada BAB V Bidang Pemberdayaan Masyarakat Desa mengamanahkan, yaitu: a) Meningkatkan kegiatan pelatihan usaha ekonomi, pertanian, perikanan dan perdagangan kerja sama dengan pihak ketiga; b) Meningkatkan pelatihan teknologi tepat guna dan ikut serta dalam setiap kegiatan; dan c) Meningkatan kapasitas masyarakat, dengan 
mempersiapkan anggaran dan kerja sama dengan pihak ketiga untuk kelompok: kader pemberdayaan masyarakat Desa, kelompok usaha ekonomi produktif; kelompok pengrajin, kelompok pemuda, dan kelompok perempuan; serta kelompok warga miskin.

Berdasarkan uraian RPJM desa di atas dan jika dikaitkan dengan UU Desa, maka potensi yang ada di desa ini memiliki nilai strategis yang luar biasa, karena secara geo-strategis Desa Sruni terletak pada posisi yang sangat menguntungkan, yaitu berada pada lintas perdagangan antar desa dan antar kecamatan dan kabupaten yang potensial. Arah kebijakan dan strategi yang dibangun telah disesuaikan dengan kondisi obyektif berdasarkan kajian hasil musyawarah pembangunan desa. Hasil percontohan budi daya padi organik pada tahun 2016 selama dua musim tanam di Desa Sruni secara empiris belum mengungkit kesadaran kritis masyarakat petani untuk mengadopsi inovasi tepat guna melalui organic farming tersebut baik terhadap budi daya padi, palawija, sayuran maupun buah-buahan, perikanan, dan peternakan. Fenomena tersebut mengakibatkan ketersediaan produk-produk bahan pangan yang bersih dari bahan-bahan kimiawi (sintesis) sulit untuk didapatkan oleh warga setempat. Implikasi berikutnya adalah gaya hidup sehat yang diharapkan dalam lingkungan keluarga dan masyarakat juga belum bisa diwujudkan dalam kehidupan nyata.

Fakta di lapangan menunjukkan bahwa berbagai penyakit yang diderita oleh warga masyarakat cukup beragam akibat kebiasaan mengkonsumsi bahan pangan yang mengandung bahan-bahan kimia yang berasal dari tanaman pangan-hortikultura, perikanan, dan peternakan. Gaya hidup sehat yang senentiasa diguangkah oleh pemerintah dan stakeholders lainnya juga sulit diwujudkan di Desa Sruni. Oleh karena itu, menjadi sangat penting perlu ada upaya mendorong warga masyarakat untuk melakukan perubahan pola pikir dan pola tindak menuju go organik melalui pendekatan sistem pertanian terpadu. Sistem ini menjadi sangat relevan karena tidak ada satu limbah produksi dari berbagai kegiatan pertanian dalam arti luas yang terbuang percuma. Limbah peternakan ikan lele dapat dijadikan pupuk organik cair buat tanaman, air seni dan kotoran ternak hewan dapat dijadikan pupuk organik, limbah jerami dan tanaman palawija berbasis organik juga dapat dikonsumsi oleh hewan ternak termasuk ampas tahu yang kedelai berasal dari budi daya organik, dan pembuatan pelet pakan ternak ikan juga terbuat dari bahan-bahan organik sehingga hasil ikannya bebas dari bahan kimia, sehingga bebas untuk dikonsumsi. Fenomena ini jika dilakukan secara berkelanjutan, maka implykasinya akan terwujud gaya hidup sehat di lingkungan masyarakat. Maka tujuan kegiatan program IbDM ini adalah mengoptimalkan penyedian produk-produk pertanian yang berbasis organik untuk menuju hidup sehat.

\section{METODE PELAKSANAAN KEGIATAN}

\section{Lokasi dan Partisipan}

Kegiatan IbDM dilaksanakan di Desa Sruni, Kecamatan Jenggawah, Kabupaten Jember, Jawa Timur pada April-Desember 2017. Mitra dari kegiatan ini adalah petani di Desa Seruni.

\section{Metode Pendekatan untuk Menyelesaikan Masalah Mitra}

Pendekatan yang dilakukan untuk menyelesaikan permasalahan mitra melalui beberapa pendekatan seperti persuasif (penyadaran), partisipatif (parisipatory action), pemberdayaan (capacyty buliding) dan inter entrepreneurial development. Guna menyepakati penentuan persoalan prioritas mitra, maka dilakukan dengan cara diskusi kelompok terarah secara partisipatif beberapa kali sebelum kegiatan ini dirancang. Upaya penguatan kapasitas SDM sasaran, maka dilakukan pendekatan melalui sosialisasi baik di tingkat desa mapun dusun (terdiri dari empat dusun), desiminasi dan pelatihan model participatory dilakukan untuk beberapa kali kegiatan sesuai dengan kebutuhan program dengan melibatkan stakeholders. Adapun kegiatan sistering desa (pendampingan) selama delapan bulan, yaitu sejak bulan April-Desember 2017 baik oleh tim pelaksana maupun Sembilan orang mahasiswa (dua orang mahasiswa per dusun dan satu koordinator tim pendamping mahasisiwa)sesuai dengan kompetensi masing-masing (multi disiplin).

Pendekatan sosialisasi yang dilakukan selama lima kali berturut-turut, yaitu sosialisasi di tingkat desa yang diikuti oleh 59 orang, di Dusun Krajan diikuti oleh 21 orang, di Dusun karang Kokap diikuti oleh 23 orang, di Dusun Leces diikuti oleh 17 orang, dan di Dusun Darungan diikuti oleh 19 orang. Adapun materi dalam sosialisasi ini adalah informasi akan dicanangkannya sistem pertanian terpadu berbasis organic farming dan sekaligus dalam rangka pemulihan kesuburan tanah. Selanjutnya dilakukan 
siklus desa organik yang terdiri beberapa tahapan hingga terbentuknya OFI (Organic Farming Institute) dan renstragonik, serta agen desa organik (ADO).

Selanjutnya desiminasi dan pelatihan dilakukan beberapa kali, yaitu pembuatan pupuk organik yang berlokasi di Dusun Krajan yang diikuti oleh 19 orang termasuk OFI dari perwakilan empat dusun, dan pembuata pupuk cair (POC) di Dusun Darungan yang diikuti oleh 15 orang perwakilan empat dusun. Agar pengetahaun dan keyakinan OFI semakin kuat, maka dilakukan studi banding ke Gapoktan AlBarokah, Desa Lombok Kulon, Kecamatan Wonosari, Kabupaten Bondowoso, Jawa Timur yang melibatkan OFI, tim pelaksana, TPM, dan kepala desa, dimana gapoktan tersebut sudah menerapkan budi daya padi organik selama 10 tahun.

Penerapan program sistem pertanian terpadu berbasis organic farming dilakukan oleh masingmasing anggota OFI terbatas pada lahan sawah dan tegalan/pekarangan yang dikuasai. Sebelum proses penerapan, dilakukan kegiatan sistering desa (pendampingan) oleh tim pelaksana dan TPM yang dimulai dengan analisa tanah pada Laboratorium Puslit Kakao Indonesia untuk memastikan kadar unsur hara yang dikandungnya sebelum diterapkan organic farming. Pendampingan terus dilakukan hingga tanaman tumbuh dan berkembang sesuai pertumbuhan normal. Selain itu, dilakukan juga proses monitoring dan evaluasi baik internal maupun eksternal guna memastikan program ini berjalan sesuai rencana dan pedoman yang ditetapkan.

Pada konteks evaluasi, salah satu cara untuk mengetahui keberhasilan program ini adalah dengan menyebarkan angket penilaian yang dilakukan oleh tim pelaksana, salah satunya adalah indikator tingkat partisipasi masyarakat petani. Dengan demikian partisipasi secara terperinci atas peran mitra dapat diuraikan sebagai berikut: 1) Bersedia selalu melakukan koordinasi dengan tim pelaksana dan pihak-pihak yang berkaitan dengan pelaksanaan program dan terlibat secara aktif dalam seluruh kegiatan dan 2) Bersedia untuk melanjutkan program yang telah dilaksanakan secara mandiri dan berkelanjutan, serta bersedia mengembangkan agen desa organik (AGO) dan sentra-sentra produksi di seluruh dusun dari hulu ke hilir sebagai bentuk pengejawantahan kebutuhan masyarakat, sehingga OFI menjadi lembaga yang mandiri secara berkelanjutan.

\section{HASIL DAN PEMBAHASAN}

\section{Persiapan Pelaksanaan Program}

\section{- Rapat koordinasi tim pelaksana}

Sejak tanggal 21 April 2017 tahapan persiapan pelaksanaan kegiatan IbDM desa organik ini dilaksanakan, yaitu dimulai dari rapat koordinasi tim pelaksana untuk merancang pola dan mekanisme kegiatan (Gambar 1). Pada agenda ini tim bersepakat membagi tugas kegiatan dengan melibatkan sembilan orang mahasiswa sebagai tenaga pendamping mahasiswa (TPM) untuk ikut menfasilitasi pelaksanaan program di lapangan yang dirancang berjalan selama 8 bulan. Mahasiswa yang dilibatkan berasal dari program studi agroteknologi dan agribisnis yang lebih dekat dengan jenis kegiatan IbDM desa organik ini. Pendamping mahasiswa dari Program Studi Agroteknologi diharapkan dapat memberikan pemahaman dan penguatan pada aspek sistem pertanian terpadu sedang pendamping yang berasal dari mahasiswa Program Studi Agribisnis untuk mengawal pada sisi manajemen agribisnis, strategi, marketing, membangun kemitraan usaha, pemahaman agroindustri/agribisnis termasuk dalam pembukuan sederhana.

\section{- Koordinasi dengan pihak terkait dan persiapan pelatihan pratugas bagi TPM}

Selanjutnya tim melakukan koordinasi pada mitra untuk agenda sosialisasi awal program IbDM desa organik, yaitu pada tanggal 09 Mei 2017 kepada mitra (Kepala Desa Sruni). Selanjutnya pada tanggal 13 Mei 2017, tim pelaksana melakukan rapat koordinasi untuk menyiapkan kegiatan pelatihan pra tugas bagi TPM yang akan diterjunkan ke lapangan. Demkian pula, tim pelaksana menyiapkan logistik berupa berbagai jenis atribut yang meliputi: banner, baliho,

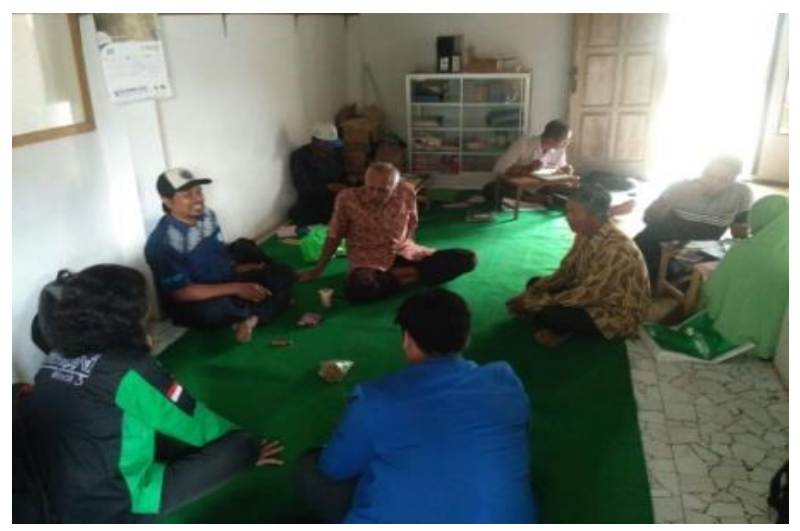

Gambar 1 Rapat koordinasi tim pelaksana kegiatan IbDM. 
poster, leaflet, stiker, kaos tim organik, dan jenis atribut lainnya dalam rangka sosialisasi dan publikasi kehadiran program IbDM desa organik di Desa Sruni, Kecamatan Jenggawah, Kabupaten Jember.

\section{- Pelatihan pratugas bagi tenaga pendamping mahasiswa}

Sebelum dimobilisasi, tenaga pendamping terlebih dahulu dilatih untuk memahami substansi program IbDM desa organik dan teknis implementasi di lapangan. Pelatihan ini dilaksanakan dua hari, yaitu pada tanggal 15-16 Juni 2017 di ruang kuliah dan Green House Fakultas Pertanian, Universitas Muhammadiyah (UM) Jember. Materi yang disampaikan meliputi pengenalan program, sistem pertanian terpadu, organic farming, teknis pendampingan, makna seorang pendamping berikut tugas-tugas tenaga pendamping, filosofi pemberdayaan masyarakat dan pola hubungan antara pendamping dengan komunitas yang didampinginya. Selain itu, juga menghadirkan Kepala Desa Sruni (lokasi sasaran program) sebagai trainer (pemandu) dengan materi gambaran profil Desa Sruni, pola hubungan sosial, potensi desa organik dan informasi lainnya yang terkait.

\section{Sosialisasi Awal}

Pelaksanaan sosialisasi awal program IbDM desa organik telah dilakukan pada tanggal 03 Juli 2017 yang dihadiri oleh peserta yang berasal dari unsur gapoktan, lima unit kelompok tani, empat kepala dusun, beberapa unsur RW/RT yang berasal dari Dusun Kraja, Leces, Karang Kokap, dan Darungan. Selain itu, peserta juga berasal dari unsur karang taruna, tokoh pemuda yang peduli pada kelestarian lingkungan, PKK, Kopwan Lestari, LPMD, BPD, Babinsa, dan HKTI. Adapun yang bertindak sebagai narasumber adalah full team dan Pejabat Dinas Pertanian Kabupaten Jember yang diawali dengan acara pembukaan yang dihadiri oleh Camat dan Danramil Jenggawah. Agenda sosialisasi awal ini juga dibuka sesi diskusi yang membawa suasana menjadi lebih dinamis. Kegiatan sosialisasi awal terlihat pada Gambar 2.

Materi sosialisasi pada hakekatnya adalah bentuk pengenalan, pemberitahuan, dan ijin kepada masyarakat bahwa Desa Sruni menjadi lokasi sasaran program IbDM desa organik yang dilaksanakan oleh UM Jember yang didanai oleh Kemenristekdikti. Warga masyarakat diharapkan dapat menyiapkan dirinya untuk berpartisipasi aktif dalam kegiatan dimaksud dalam upaya memecahkan massalah terdegradasinya kesuburan lahan pertanian, merosotnya kualitas pangan, kian merebaknya penyakit akibat racun dalam makanan yang telah dikonsumsi, dan pentingnya membangun usaha agribisnis berbasis organik guna meningkatkan derajad kesehatan dan kesejahteraan masyarakat. Hadir pula wartawan Harian Radar Jember (Jawa Pos Grup) untuk meliput acara dimaksud dan selanjutnya disiarkan ke ruang publik beberapa hari berikutnya.

Sosialisasi bukan hanya dilakukan di kantor kepala desa, namun disertai dengan pemasangan media lainnya seperti banner, baliho, poster, leaflet, pamflet, kaos seragam OFI, dan stiker di seluruh penjuru desa (empat dusun), yaitu pada titik-titik strategis termasuk yang membentang di jalan poros desa. Penyebaran media ini bertujuan agar proses sosialisasi atau penyiaran. Program desa organik di lokasi sasaran dapat tersosialisasi secara akseleratif. Warga yang jauh dari lokasi kantor desa seperti yang bermukim di Dusun Darungan, Leces, dan Karang Kokap dapat mendengar dan mengetahui bahwa akan hadir sebuah program desa organik.

\section{Pelaksanaan Siklus Desa Organik}

Sebelum TPM diterjunkan guna menfasilitasi pelaksanaan Siklus Desa Organik, kembali tim pelaksana melakukan coaching kepada mereka dengan harapan agar realisasinya berjalan dengan lancar, efektif, dan efisien. Kegiatan coaching bagi TPM dilaksanakan pada tanggal 09 Juli 2017 yang dihadiri oleh 9 orang TPM. Pada akhir coaching telah disepakati bahwa TPM mulai bekerja dan terjun memulai proses pelaksanaan siklus desa organik pada tanggal 17 Juli 2017. Sebelumnya TPM beberapa kali berkoordinasi dengan keempat kepala dusun dan gapoktan/ poktan untuk menentukan waktu, tempat, undangan, peserta yang diundang, dan segala

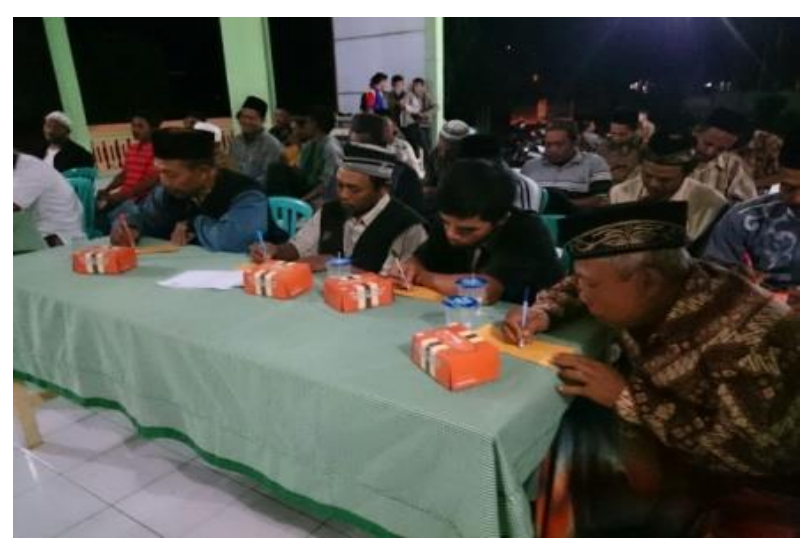

Gambar 2 Kegiatan sosialisasi awal. 
perlengkapan yang dibutuhkan. Koordinasi berlangsung sejak tanggal 10-15 Juli 2017.

Pelaksanaan siklus desa organik dimulai dari tahapan Rembug Kesiapan Masyarakat dan Kerelawanan (RKMK), Refreksi Pertanian Berkelanjutan (RPB), Pemetaan Swadaya dan Pembentukan ADO (PSPA), dan Pembentukan OFI dan Penyusunan Program Rencana Strategis Desa Organik (Renstragonik) jangka panjang (3 tahun) dan jangkan pendek (1 tahun), sinergei dengan renstra pemda, pengorganisasian pembentukan ADO, implementasi dan monev, dan review partisipatif: resntragonik dan kelembagaan. TPM dibagi menjadi empat gugus tugas (task force) atau empat kelompok berdasarkan jumlah dusun yang ada di Desa Sruni dengan tujuan agar proses pelaksanaannya tidak memerlukan waktu yang panjang yang bekerja secara simultan.

Tahapan berikutnya adalah RKMK dilaksanakan masing-masing di Dusun Darungan, Karang Kokap, Krajan, dan Leces. Kegiatan tersebut dilaksanakan pada malam hari (setelah Isya') mengingat siang hari warga tidak bisa diganggu aktivitas pekerjaan rutinnya. Tempat pelaksanaan kegiatan ini di halaman rumah kepala dusun, musholla, dan balai dusun. Selanjutnya pada tanggal 20 Juli 2017, seluruh dusun melaksanakan siklus Refreksi Pertanian Berkelanjutan (RPB) secara bersamaan di waktu malam hari dengan tempat yang sama. Sementara itu, Dusun Krajan dan Darungan pada tanggal 22 Juli 2017 melaksanakan tahapan siklus Pemetaan Swadaya dan Pembentukan ADO (PSPA), sedangkan Dusun Karang Kokap dan Leces melaksanakan pada tanggal 23 Juli 2017.

Tahapan siklus pembangunan OFI yang diawali oleh penjaringan calon anggota OFI tingkat basis (dusun/RW/RT) dilakukan berturut-turut pada tanggal 25-27 Juli2017 untuk masing-masing di Dusun Krajan, Leces, Darungan, dan Karang Kokap. Sebelum dilaksanakan pembangunan OFI di tingkat desa, TPM bersama tim pelaksana melakukan penyusunan draf rencana strategis desa organik (Renstragonik) jangka panjang (3 tahun) dan jangkan pendek (1 tahun) berdasarkan hasil kegiatan PSPA mulai tanggal 20-22 Juli 2017. Penyusunan draf dokumen ini dimaksudkan untuk memudahkan pada saat setelah terbentuknya OFI. Selain itu, pada tanggal 29 Juli 2017, tim pelaksana menyusun draf AD/ART OFI yang akan dibahas dan diplenokan (dimufakati) oleh peserta perwakilan semua unsur warga masyarakat pada saat pembangunan OFI tingkat Desa. Demikian pula Tim Pelaksana juga menfor- mulasikan mekanisme dan tata tertib pemilihan OFI dengan merujuk pada buku pedoman pelaksanaan desa organik yang telah disusun sebelumnya.

Pelaksanaan pembangunan OFI tingkat desa telah dilaksanakan pada tanggal 05 Agustus 2017 dan berhasil menetapkan 11 orang anggota OFI di mana model kepemimpinannya bersifat kolektif kolegial, AD/ART, dan tata tertib pemilihan OFI. Selanjutnya tim pelaksana, TPM dan Kader Desa Organik (Kado) telah menfasilitasi kegiatan penyusunan resntragonik pada tanggal 09 Agustus 2017 berikut Renta. Akhirnya pada tanggal 15 Agustus 2017 seluruh Agen Desa Organik (ADO) sudah terbentuk sebanyak 9 unit yang terdiri dari ADO pupuk orgaik, pestisida organik, padi organik, jagung organik, kedelai organik, sayuran organik, agroindustri organik, lembaga pemasaran organik, dan kakao organik.

\section{Studi Banding Pertanian Organik}

Pelaksanaan studi banding dengan tujuan lokasi sentra produksi padi dan beras organik di Desa Lombok Timur, Kecamatan Wonosari, Kabupaten Bondowoso dilaksanakan pada tanggal tanggal 25 Agustus 2017. Produsen padi dan beras organik adalah lima kelompok tani yang tergabung dalam Gapoktan AL-Barokah yang dimulai sejak tahun 2012, di mana perusahaan tersebut dikenal dengan Botanik (Bondowoso Beras Organik). Studi banding diikuti oleh tim pelaksana (empat orang), TPM (sembilan orang), dan OFI (lima orang). Hasil studi banding tersebut dapat memberikan banyak manfaat bagi OFI dan Tim Pelaksana program IbDM, baik dari sisi pengetahuan, pengalaman empiris, kelembagaan, dan penguatan akses jaringan serta penguatan keyakinan melakukan perubahan menuju go organic. Pada bahasan berikut ini akan diuraikan proses kronologis perjalanan studi banding disertai dengan isi kegiatannya yang meliputi:

\section{- Perkenalan dan diskusi}

Penanggung jawab program IbDM menyampaikan maksud kedatangannya dan sekaligus menguraikan tujuan program dan kaitannya dengan OFI selaku bagian desa binaannya. Bapak Mulyono yang didampingi oleh Koordinator BPP (Bapak Rubiyanto) menerangkan tentang ketertarikan anggota petaninya untuk berpartisipasi dalam budi daya padi organik. Diawali dengan implementasi program Pemerintah Kabupaten Bondowoso melalui dinas pertanian mengundang anggota petani dari enam gapoktan di 
daerahnya untuk mengikuti Sekolah Lapang Pertanian Organik (SLPO). Sekolah tersebut berlangsung beberapa gelombang yang diikuti oleh lima orang dari masing-masing gapoktan atau total peserta latih berjumlah 30 orang selama seminggu per gelombang. Pengaruh penyelenggaraan SLPO sangat signifikan pengaruhnya terhadap respons dan partisipasi petani terhadap budi daya padi organik.

Dijelaskan pula bahwa agar petani dapat secara persuasif untuk terlibat dalam usaha tani padi organik, maka diyakinkan kepada anggota kelompok tani pada saat SLPO bahwa ditegaskan jika terjadi perubahan perlakukan dari anorganik (konvensional) menuju sistem organik, maka secara otomatis produktivitasnya menurun hingga 33,33\% selama dua tahun (6 musim), namun penurunnya semakin berkurang. Misalnya produktivitas padi dengan perlakukan konvensional memperoleh hasil 6,2 ton/ha, maka awal perlakukan organik akan menurun produktivitasnya menjadi 4,2 ton/ha, musim berikutnya 4,8 ton/ha, 5,2 ton/ha hingga pada musim keenam berikutnya (setelah menjalani 2 tahun), maka produktivitas padi kembali normal $(6,2$ ton/ha dan bisa lebih) dan lahan kembali sehat dan subur bebas unsur hara senyawa kimiawi dengan rendemen rata-rata $52 \%$.

Walaupun bobot padi organik menjadi turun selama masa konversi, namun harga gabah kering sawah (KS) jauh lebih tinggi daripada gabah konvensional. Misalnya harga padi konvensional KS Rp 4.000/kg, maka harga padi organik bisa mencapai di atas Rp 5000/kg. Selanjutnya Bapak Mulyono kembali menggambarkan strateginya dalam mendorong dan memotivasi anggotanya serta mempertahankan keyakinan atas pentingnya padi organik, pada saat panen, Bapak Mulyono membeli gabah milik anggotanya dengan menambah harga $\mathrm{Rp}$ $1.000 / \mathrm{kg}$ dari harga padi yang berlaku umum. Oleh karena itu, anggota petani tetap loyal dan mempertahankan untuk membudidayakan padi secara organik daripada kembali kepada sistem konvensional.

Seluruh kelompok tani yang terhimpun dalam Gapoktan Al-Barokah tetap bertahan hingga sekarang dan bahkan dengan jumlah luas lahan yang kian bertambah. Proses produksi beras organik di Gapoktan Al-Barokah diawali dari proses usaha tani yang diaplikasikan secara organik pula. Kawasan Desa Lombok Kulon di mana gapoktan berada, tiga musim tanam terdapat ketersediaan air irigasi secara terus menerus yang berasal dari air sumber Gunung
Raung. Oleh karena itu, petani dapat menanam padi secara terus menerus selama setahun tanpa ada pergiliran tanaman. Meskipun air irigasi yang tersedia saat ini diasumsikan bebas dari bahanbahan kimiawi, namun masih diupayakan setiap pintu masuk air ke sawah yang mengalir dari saluran irigasi tersier/sekunder, wajib dibuat buffer (embung) dengan ditanami oleh jenis tanaman enceng gondok, kangkung atau jenis tanaman lainnya yang dapat menyerap dan menfilter bahan-bahan kimiawi yang datangnya dari sungai/kanal dan saluran sekunder yang dikuatirkan membawa bahan-bahan berbahaya. Selain itu, itu buffer tersebut dibuat sebagai indikator steril kimiawi (murni organik) jika terdapat ikan, kodok, belut, dan jenis hewan air lainnya yang masih tetap hidup normal.

Awalnya luas lahan sawah yang diusahakan padi organik tercatat seluas 72,9 ha, tetapi seiring dengan berjalannya waktu ternyata sampai dengan saat ini tinggal tersisi 54,5 ha yang masih layak tersertifikasi organik oleh Lembaga Sertifikasi Organik (LeSO) Mojokerto. Ternyata memproduksi beras organik tidaklah mudah yang dibayangkan, karena mulai dari aspek kelembagaan, administrasi, kondisi lahan, udara, dan perilaku penduduk/warga di kawasan lahan padi organik hasruslah steril dari pencemaran lingkungan. Pada aspek administrasi, LeSO mengasesment dimulai dari dokumentasi data lahan sawah dan pemiliknya berikat letak lokasi per petak. Dokumen tersebut harus disimpan dalam map dengan kode tertentu tiap petak tiap pemilik lahan. Jika LeSO melakukan inspeksi tiap tahun, maka assesor tersebut sebelum turun ke sawah, terlebih dahulu meminta data petak di sekretariat gapoktan untuk memastikan titik lokasi lahan yang hendak diassesment. Jika terdapat data yang berbeda antara yang ada di dokumen dengan fakta di lapangan, maka petak lahan tersebut dicoret dan dianggap gugur organik.

Lebih dari satu dekade sejak dimulainya budi daya padi organik, tiap 3 tahun Botanik selalu lulus sertifikasi organik. Banyak pengusaha yan tertarik dengan produksi beras organik produksi Gapoktan Al-Barokah mulai dari beras hitam, merah, hingga putihnya. Oleh karena itu, ada pengusaha eksportir yang tertarik untuk ikut membantu mengekspor beras organik Botanik ke Amerika Latin dan Eropa Barat. Sehingga satu tahun yang lalu disertifikasi ekspor melalui lembaga sertifikasi organik internasioanl melalui penunjukan lembaga sertifikasi nasional yang berkedudukan di Bogor. Pada November tahun 
2017 SK Sertifikasinya sudah terbit dan dapat mengekspor beras ke luar negeri dengan kapasitas 18 ton/bulan. Adapun masa berlaku sertifikasi organik internasional hanya berlangsung satu tahun. Upaya ini mendapat dukungan kuat dari Bank Indonesia (BI) wilayah kerja Jember dengan memberikan banyak fasilitas seperti mesin pak beserta mesin jenset dan penggerak alat packing beras organik. Bukan hanya peralatan tersebut, mobil operasional juga dibantu BI Jember untuk memperlancar aktivitas operasional termasuk seperangkat komputer guna mempermudah administrasi, LCD, sound system dan fasilitas lainnya guna mendukung aktivitas gapoktan.

\section{- Visit menuju laboratorium pembuatan bahan-bahan organik, sekretariat Gapoktan Al-Barokah dan lahan padi organik}

Kunjungan lapang diawali ke Pusat Pengembangan Agensia Hayati sebagai bentuk penggunaan pestisida organik. Laboratorium dan produsen pestisida hayati ini merupakan salah satu syarat produksi padi dan beras organik yang wajib dimiliki oleh produsen. Produsen ini merupakan bagian tugas pokok dan fungsi dari Internal Control System (ICS) dimana memiliki otoritas dan mengendalikan keorganikan mulai dari budi daya padi organik hingga produksi beras organik. Sebelum diajukan sertifikasi organik nasional, ICS bertugas melakukan assement terlebih dahulu dan bila dinyatakan lulus, maka dilanjutkan pengajuannya kepada lembaga sertifikasi organik (LeSO) Mojokerto.

Kunjungan ke lahan padi organik di mana jarak lokasinya dari gudang seleb, pengering, pusat pengembangan agensia hayati, dan gedung pakcing sekitar $2 \mathrm{~km}$. Varietas padi yang dibudidayakan juga tidak berbeda, yaitu meliputi IR 64, Chiherang, Pandan Wangi, Impari, Mentik Wangi, Sintanor, Cimbogo, dan lain-lain. Produktivitasnya relatif sama dengan model budi daya padi konvensional, perawatannya juga tidak berbeda hingga umur tanaman relatif sama, yaitu sekitar 100 HST. Selain itu, gapoktan juga membudidayakan padi hitam dan merah organik untuk memenuhi permintaan pasar yang dikemas dalam ukuran per kg dengan harga $\mathrm{Rp}$ $30.000 / \mathrm{kg}$. Studi banding diakhiri berdiskusi lagi di sekretariat Gapoktan Al-Barokah dengan tema penguatan kelembagaan dan adminitrasi. Sebab kedua variabel penting tersebut menjadi titik pangkal dari proses sertifikasi padi dan beras organik. Selain itu, diskusi juga diarahkan kepada kemungkinan sinergitas yang hendak dibangun oleh kedua belah pihak terutama dalam aspek penguatan pengetahuan, keterampilan dan pemasaran produk.

\section{Pelatihan Pembuatan Bahan-Bahan Organik - Pupuk organik padat (Bokasi)}

Pupuk organik bokashi merupakan pupuk organik padat yang berasal dari fermentasi bahan organik di mana kaya akan unsur $\mathrm{C}$ dan baik untuk memperbaiki struktur tanah serta mengandung unsur makro dan mikro dalam jumlah terbatas. Metode yang dipakai menggunakan aerob dan anaerob, bioaktivator menggunakan pabrikan dan mol yang sudah dibuat. Selanjutnya akan dibandingkan hasil Bokasi dari kedua bioaktivator tersebut berdasarkan kandungan (analisa laboratorium jika memungkinkan) dan waktu fermentasi serta efeknya terhadap pertumbuhan dan perkembangan tanaman.

\section{- Pupuk organik cair (POC)}

Pupuk organik cair merupakan nutrisi yang berasal dari fermentasi bahan organik dimana mengandung unsur hara lengkap makro dan mikro. Kandungan utama dalam POC tergantung dari bahan dasar yang dipakai dan tujuan dibuatnya bahan tersebut. Biasanya bahan ini dipakai untuk pertumbuhan tunas, pembungaan, dan kualitas buah. POC yang akan dikembangkan dalam kegiatan ini adalah POC dengan kandungan $\mathrm{N}, \mathrm{P}$, dan $\mathrm{K}$ relatif tinggi serta dilengkapi dengan ZPT alami. Untuk itu akan dipakai bahan yang berasal dari kotoran sapi, rebung, bonggol pisang, buah-buahan, sayuran, dan dedak. Bioaktivator menggunakan pabrikan dan mol yang sudah dibuat. Selanjutnya akan dibandingkan hasil POC dari kedua bioaktivator berdasarkan kandungan (analisa laboratorium jika memungkinkan) dan waktu fermentasi serta efek nya terhadap pertumbuhan dan perkembangan tanaman.

\section{- Pestisida organik (Nabati)}

Secara Alami tumbuhan memiliki senjata untuk menghadapi serangan dari luar. Kemampuan itu hasil interaksi antara tanaman dan hama yang telah berlangsung jutaan tahun. Serangan hama menyebabkan kematian yang rentan, lewat proses evolusi sehingga lahir populasi yang beradaptasi tinggi, kelompok tersebut berhasil menciptakan zat-zat kekebalan. Pestisida diartikan sebagai zat yang dapat bersifat racun menghambat pertumbuhan/perkembangan tingkah laku, perkembangbiakan kesehatan, me- 
mengaruhi hormon, penghambat makanan, membuat mandul sebagai pemikat, penolak, dan aktivitas lain yang memengaruhi organisme pengganggu tanaman. Sebelum manusia dapat mengolah unsur-unsur kimia menjadi pestisida, mereka menggunakan cairan tumbuhan yang ada di sekitarnya untuk mengendalikan dan memberantas hama serta penyakit tanaman. Berbagai macam tumbuhan dapat digunakan sebagai pestisida nabati dan cara pembuatannnya.

\section{Penerapan Sistem Pertanian Organik}

OFI menerapkan sistem pertanian organik pada sebagian kecil lahan yang dimilikinya untuk budi daya jagung. Sebab pada momentum tersebut masuk pada musim kemarau di mana di daerah Desa Sruni sebagian kecil hanya bisa ditanami padi secara terus menerus. Total lahan sawah yang dikelola dengan menerapkan konsep organic farming adalah seluas 5,25 ha. Proses pemberian pupuk organik dilakukan secara semi organik pada budi daya jagung yang diperoleh dari ADO organik serta ADO pestisida hayati. Bahan-bahan organik baik berupa pupuk cair maupun padat diproduksi berbahan kotoran dan air kencing ternak sapi yang dimiliki oleh hewan ternak kepala desa maupun warga penduduk lainnya. Selain itu, ADO Organik juga memproduksi pupuk kompos dengan memanfaatkan limbah jerami dan jagung yang keterampilannya dikuasai sejak lama atas dampingan PPL dan gapoktan setempat.

Produktivitas jagung semi organik yang dicapai dalam penerapan organic farming terhadap budi daya jagung relatif turun (5,9 ton/ha) dibanding sebelumnya (6,7 ton/ha). Namun demikian para pelaku memahami atas turunnya produktiviats tersebut karena secara empiris penerapan organik pada tahapan awal dipastikan mengalami penurunan. Diestimasi dan ekspektasi pada tahun ketiga akan kembali naik bahkan lebih tinggi dibandingkan dengan sebelum penerapan organic farming.

Sementara itu, penerapan sistem pertanian organik pada tanaman hortikultura (buah dan sayur) masih diaplikasikan pada lahan pekarangan dengan menggunakan media tanam polibag ukuran besar (Gambar 3). Budi daya buah dan sayur ini dipadukan dengan peternakan ikan lele dombo baik menggunakan media kolam tanah, plastik, maupun media tong. Air kolam yang sudah demikian keruh berwarna hijau, selanjutnya dikuras dan dialirkan pada tanaman buah dan sayur yang dibudidayakan. Bahkan di lahan pekarangan kepala desa, pada lahan ini juga dibudidayakan ternak sapi lokal untuk diambil air seni dan kotorannya. Guna menunjang penyediaan stok pangan ternak tersebut, maka disepanjang pinggiran lahan pekarangan dibudidayakan rumput gajah yang sering kali dialiri limbah air ternak lele maupun kotoran dan air seni ternak sapi.

\section{Analisis Laboratorium Lahan Sawah}

Sebelum diaplikasikan penyuburan lahan sawah, maka terlebih dahulu ditentukan kandungan unsur hara termasuk kandungan senyawa organiknya. Pada tanggal 18 Agustus 2017, TPM bersama perwakilan OFI mengambil sampel tanah untuk diuji di laboratorium untuk menentukan kandungan unsur hara dan organik di lahan yang hendak dijadikan demonstrasi plot (demplot) perlakuan organik. Sampel tanah yang diambil dari lima titik lahan demplot, lalu dikompilasi dan dianalisis laboratorium di Pusat Penelitian Kopi dan Kakao Indonesia. Hasil analisis laboratorium terhadap sampel tanah demplot pada lima titik tersebut menunjukkan kondisi yang sangat memprihatinkan. Artinya lahan demplot tersebut dalam kondisi yang tidak subur lagi akibat penggunaan bahan-bahan kimiawi yang berlebihan.

\section{Pemetaan Bahan Baku Pembuatan Bahan- Bahan Organik}

Pada tanggal 20 Agustus 2017, Tim Pelaksana melakukan pemetaan terhadap sumber daya lokal baik jerami (limbah pertanian) dan limbah ternak. Berdasarrkan hasil siklus desa organik dengan tahapan pemetaan swadaya dan pembangunan ADO, dapat ditindaklanjuti terhadap identifikasi titik-titik lokasi sumber daya bahanbahan pembuatan bahan-bahan organik (pupuk dan pestisida organik). Kegiatan pemetaan ini dimaksudkan untuk memastikan dan menjamin

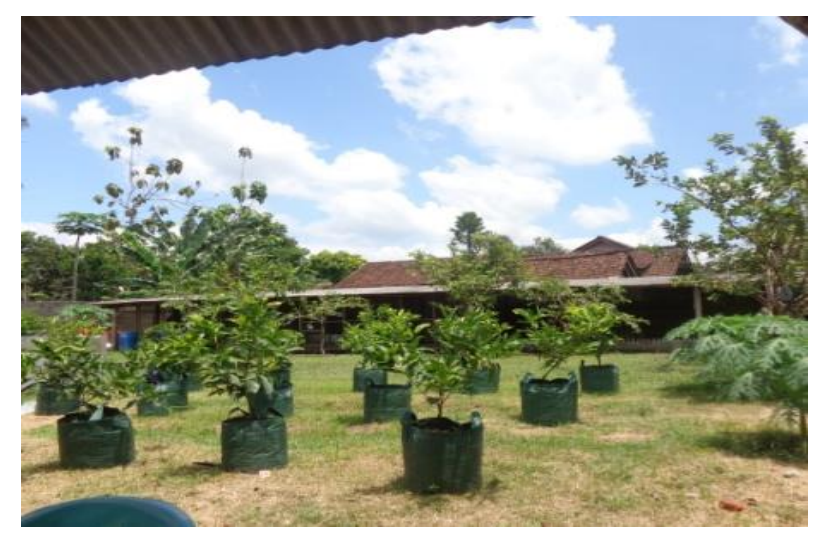

Gambar 3 Penerapan sistem pertanian organik pada buah dalam pilibag di pekarangan rumah. 
keberlangsungan sistem pertanian organik berjalan di desa binaan UM Jember.

\section{Pemetaan Lahan Demplot}

Guna memeroleh lahan di suatu kawasan dengan kondisi yang terlokalisir dari potensi kontaminasi sistem pertanian konvensional, maka diperlukan pemetaan yang cermat agar proses aplikasi sistem pertanian organik dapat berjalan seperti yang diharapkan. Kegiatan pemetaan lahan demplot berbasis organik, dilakukan pada tanggal 21 Agustus 2017 yang didampingi oleh Kepada Desa Sruni serta beberapa OFI. Diperoleh lahan demplot seluas 3 ha, yaitu lahan kas desa dan sebagian sawah milik ketua OFI yang luasnya 0,25 ha. Hasil pertanian jagung organik diharapkan dapat memberikan motivasi anggota kelompok tani dan berpartisipasi untuk mengusahakan tanaman organik pula.

\section{Review Partisipatif}

Review partisipatif terhadap konsep dan pelaksanaan program untuk mengukur capaian indikator keberhasilan program sebagai bahan penyempurnaan pada realisasi tahun kedua dan penilaian kinerja kelembagaan OFI. Selama satu periode pelaksanaan program IbDM desa organik, diperlukan review untuk memastikan terhadap konsep program apakah sudah berjalan efektif atau belum. Kegiatan review ini dilakukan secara partisipatif antara tim pelaksana, TPM, kades, dan OFI beserta relawan (KADO) dalam suatu forum musyawarah. Hasil review partisipatif tersebut di antaranya adalah bahwa konsep atau model yang dibangun dan diterapkan masih terasa formal oleh sebagian OFI, KADO, ADO, dan sebagian gapoktan. Perlu disederhanakan agar masyarakat petani dapat mengikutinya secara holistik dengan tidak mengabaikan substansi dan ghirrohnya.

\section{Analisis Hasil Kegiatan, Kendala yang Dihadapi, Dampak, dan Upaya Keberlanjutan Kegiatan}

Berdasarkan proses dan hasil pelaksanaan kegiatan IbDM secara umum dapat berjalan dengan baik, namun tingkat keberhasilannya tidak seperti yang diharapkan. Tingkat kedasaran warga petani relatif masih belum terungkit secara signifikan meskipun sosialisasi dilakukan cukup merata di seluruh penjuru desa. Hal ini disebabkan selain jumlah keterlibatan warga petani dalam proses pelaksanaan program ini relatif sedikit, juga persepsi, pola pikir, dan pola tindak mereka cenderung bersifat instan. Faktor penyebab lainnya adalah hasil penerapan organic farming pada tanaman jagung menunjukkan produktivitas menurun, sedang harganya relatif sama dengan hasil produksi secara konvensional. OFI dan agen-agen penggerak lain masih kurang berani secara terbuka untuk mempersuasif warga petani untuk menerapkan organic farming.

Jika dilihat dari hasil penelitian Hadi et al. (2019) di Kabupaten Jember tentang persepsi petani terhadap penerapan budi daya padi organik, maka kondisi penerapan organic farming di Desa Sruni relatif sama. Hasil penelitian tersebut mengungkapkan bahwa kurang berhasilnya penerapan organic farming di Kabupaten Jember disebabkan beberapa faktor, yaitu 1) Kurangnya pengetahuan dan peran kelompok tani dalam memberi informasi terkait organic farming (44\%); 2) Rendahnya tingkat kesadaran petani, kurang sabar dan tidak mau ruwet (12\%); 3) Minimnya informasi terkait sistem pertanian organik dari PPL setempat (24\%); dan 4) Jaminan pasar produk organik belum meyakintan para petani (20\%). Adapun faktor persepsi petani terhadap jaminan harga produk berpengaruh nyata terhadap tingkat partisipasi petani dalam penerapan budi daya padi organic.

Jika sistem pertanian terpadu berbasis organic farming diterapkan oleh petani, maka dampaknya akan sangat luas. Secara ekonomi akan memberikan keuntungan pada masyarakat petani dengan signifikan seperti halnya hasil penelitian Andreas et al. (2019) di Desa Lombok Kulon, Kecamatan Wonosari, Kabupaten Bondowoso bahwa keuntungan padi organik mencapai lebih dari Rp 14 juta/ha/musim. Secara ekologis, penerapan sistem pertanian organik ini akan memberikan kelestarian lingkungan hidup termasuk memulihkan lahan dari degradasi kesuburan, dan secara aspek sosial akan berdampak pada ketentraman warga masyarakat.

Jika dievaluasi secara umum bahwa indikator keberhasilan program ini untuk sisi psikomotorik atau actionsnya, kognitif, dan afektivitasnya masih cukup berhasil. Hal ini dapat diukur berdasarkan penilaian kinerja kelembagaan OFI bersama petani lainnya bahwa secara kelembagaan tergolong "semi berdaya" dengan total skor 30,23\%, sedangkan hasil capaian indikator keberhasilan hanya 65\% (cukup baik) dan siap go organik. Banyak kendala yang dihadapi oleh gerakan ini terutama pengurus OFI dan beberapa agen lainnya yg sudah terbentuk, di antaranya adalah persepsi petani bahwa sistem 
pertanian terpadu tergolong rumit, kebiasaan dan sifat petani yang masih cenderung menyukai proses instan, dan kesibukan yang beragam di luar bertani bagi pengurus OFI, sehingga komitmennya menjadi semakin lemah. Oleh karena itu, penerapan sistem pertanian terpadu berbasis organic farming di Desa Sruni diperlukan pendampingan yang lebih intensif dan serius oleh stakholedrs agar ketersediaan produk-produk pertanian yang sehat dapat berjalan optimal. Bahkan Pemerintah Kabupaten Jember perlu secara tegas membuat kebijakan yang mendukung terhadap go organic.

\section{SIMPULAN}

Pelaksanaan tahapan sosialisasi program IbDM ini sudah dilaksanakan dengan hasil bahwa mitra sudah memahami secara tekstual tentang konsep dari kegiatan ini dan sudah menerapkannya meskipun dalam skala terbatas. Rekayasa sosial sudah dilaksanakan dengan baik, di mana mitra mulai terbangun pola pikir dan pola tindak akan pentingnya melakukan perubahan mendasar di bidang pertanian menuju sistem pertanian terpadu berbasis organik. Realisasi studi banding ke sentra produksi padi dan beras organik Gapoktan Al-Barokah, Lombok Timur, Kecamatan Wonosari, Kabupaten Bondowoso dilaksanakan semakin mempresuasif OFI dalam go organic. Secara umum proses pelaksanaan program IbDM di Desa Sruni dapat berjalan dengan baik, namun tingkat keberhasilannya tidak seperti yang diharapkan, tingkat kedasaran warga petani relatif masih belum terungkit secara signifikan. Untuk mengukur capaian indikator keberhasilan dan kinerja OFI dengan hasil bahwa capaian indikator keberhasilan hanya 65\% (cukup baik) dengan kinerja kelembagaan OFI sebesar 30,23\% (semi berdaya) dan siap go organik. Banyak kendala yang dihadapi oleh gerakan ini terutama pengurus OFI dan beberapa agen lainnya yg sudah terbentuk, di antaranya adalah persepsi petani bahwa sistem pertanian terpadu tergolong rumit, kebiasaan dan sifat petani yang masih cenderung menyukai proses instan, dan kesibukan yang beragam di luar bertani bagi pengurus OFI, sehingga komitmennya menjadi semakin lemah.

\section{UCAPAN TERIMA KASIH}

Terima kasih penulis ucapkan kepada Direktora Riset dan Pengabdian kepada Masyarakat, Direktorat Jenderal Pendidikan Tinggi, Kementrianristekdikti Republik Indonesia yang telah mensupport dana penelitian melalui skim IbDM Tahun Anggaran 2017, sehingga penulis dapat melakukan pengabdian kepada masyarakat melalui program desa organik dan publikasi ilmiah

\section{DAFTAR PUSTAKA}

Andreas U, Hadi S, Prayuginingsih H. 2019. Dampak Program Penyuluhan Pertanian Terhadap Produktivitas Dan Keuntungan Usahatani Padi Organik Di Desa Lombok Kulon, Kecamatan Wonosari, Kabupaten Bondowoso. [Tesis]. Jember (ID): Universitas Muhammadiyan Jember.

Dinas Pertanian Kabupaten Jember. 2012. Potensi Pengembangan Pertanian Organik di Kabupaten Jember. [Internet]. [Diakses pada: 18 Maret 2012]. Tersedia pada: http:// pertanian.jatimprov.go.id/kab-jember/.

Dinas Pertanian Kabupaten Jember. 2012. Gerakan Pemulihan Kesuburan Lahan Pertanian di Kabupaten Jember. [Internet]. [Diakses pada: 25 Maret 2016]. Tersedia pada: https://es.scribd.com/doc/89140070/Strate gi-Pemulihan-Degradasi-Lahan-Kab-Jember.

Hadi S, Prayuginingsih H, Akhmadi AN. 2019. Peran Kelompok Tani dan Persepsi Petani terhadap Penerapan Budi daya Padi Organik di Kabupaten Jember. Jurnal Penyuluhan. 15 (2): 154-168. https://doi.org/10.25015/ 15201918492

IFOAM International Federation of Organic Agriculture Movement. 2009. Basic Standard of Organic Agriculture and Food Processing. Germany (DE): IFOAM. 24 page.

Kantor Desa Sruni. 2016. Profil Desa Sruni Kecamatan Jenggawah Kabupaten Jember.

Perdes No. 01 Tahun 2016. RPJM Desa Sruni Kecamatan Jenggawah Kabupaten Jember. 
PP No. 47 Tahun 2015. Perubahan Atas Peraturan Pemerintah No. 43 Tahun 2015 Tentang Peraturan Pelaksanaan UU Desa No. 06 Tahun 2014. Dalam Lembaran Negara Republik Indonesia Tahun 2015 No. 157. Jakarta.

Permentan Nomor 64/Permentan/OT. 140/5/2013. Sistem Pertanian Organik. [Internet]. [Diakses pada: 17 Agustus 2017]. Tersedia pada: www.deptan.go.id.

Santoso NK, Hartono G, Nuswantara B. 2012. Analisis Komparasi Usaha tani Padi Organik dan Anorganik di Kecamatan Sambirejo Kabupaten Sragen. AGRIC. 24(1): 63-80.

UU No. 06 Tahun 2014. Undang-Undang Desa. Dalam Lembaran Negara Republik Indonesia Tahun 2014 No. 7. Jakarta.

Widnyana IK. 2011. Upaya Meningkatkan pendapatan Petani Melalui Pendampingan Penerapan Ipteks Peningkatan Produktivitas Padi Berbasis Organik (P3B0). Majalah Aplikasi Ipteks Ngayah. 2(2): 35-43. 